\title{
Urea synthesis and degradation in sheep given pelleted-grass diets containing flaked barley
}

\author{
BY B. W. NORTON,* J. B. MACKINTOSH† AND D. G. ARMSTRONG \\ Department of Agricultural Biochemistry and Nutrition, School of Agriculture, \\ The University of Newcastle upon Tyne, 7RU NEI
}

(Received 28 May 1981 - Accepted 13 December 1981)

1. Three sheep fitted with rumen and oesophageal cannulas were given hourly the following diets in successive experiments: $1000 \mathrm{~g}$ pelleted-grass cubes/d (diet $\mathrm{A}$ ) and $700 \mathrm{~g}$ pelleted-grass cubes plus $300 \mathrm{~g}$ flaked barley/d (diet B).

2. During the final week of each 4-week dietary regimen, a balance trial was conducted and on separate days each sheep was continuously infused with $\left[{ }^{14} \mathrm{C}\right]$ urea and $\mathrm{NaH}^{14} \mathrm{CO}_{3}$ intravenously and $\mathrm{NaH}^{14} \mathrm{CO}_{3}$ intraruminally. $\mathrm{C}$ transfer rates between blood urea, blood bicarbonate and rumen bicarbonate pools were calculated from the specific radioactivity of urea and bicarbonate sampled and isotope infusion rate during each experimental period. In the same period, an oral infusion of ${ }^{51} \mathrm{Cr}$-EDTA was maintained and salivary flow rate and composition determined from samples collected from the oesophageal fistula.

3. The inclusion of flaked barley in the pelleted-grass diet significantly $(P<0.01)$ increased the apparent digestibility of organic matter (0.069), apparently digestible organic matter intake and nitrogen balance, and increased the efficiency of dietary $\mathrm{N}$ utilization from 0.059 (diet A) to 0.290 (diet B). Increased $\mathrm{N}$ balance was the result of a significant $(P<0.01)$ reduction in urinary urea excretion.

4. The rumen fluid of sheep given diet $\mathrm{A}$ had higher $\mathrm{pH}$ and bicarbonate concentrations but lower butyric acid concentrations than that of sheep given diet B. There was no significant effect of diet on total volatile fatty-acid or ammonia concentrations in rumen fluid, or on osmolality and rumen fluid dilution rate. The irreversible loss of bicarbonate from rumen fluid was markedly increased when flaked barley was included in the diet, with most of the loss occurring directly from rumen fluid.

5. Sheep given diet $A$ had higher salivary secretion rates $(18.81 / \mathrm{d})$ than those given diet $B(12.7 \mathrm{l} / \mathrm{d})$, and with the exception of urea, there was no effect of diet on the concentrations of total $\mathrm{N}$, protein $\mathrm{N}, \alpha$-amino-N, uric acid-N or bicarbonate in saliva. Urea concentrations in saliva were significantly correlated $\left(r^{2} 0.64\right)$ with blood urea concentrations, but not with salivary flow rate. Salivary secretions contributed 2.2 and $1.4 \mathrm{~g} \mathrm{~N} / \mathrm{d}$ to the rumen of sheep given diets A and B respectively, with urea forming only $45-33 \%$ of the total $\mathrm{N}$ secreted.

6. When flaked barley was included in the pelleted-grass diet, there was a significant $(P<0.01)$ decrease in urea synthesis rate (diet A $20.0 \mathrm{~g} \mathrm{~N} / \mathrm{d}$, diet B 9.7 g N/d), a significant increase in amount (diet A 2.3 g N/d, diet B 3.0 g $\mathrm{N} / \mathrm{d}$ ) and proportion (diet A 0.24 , diet B 0.57 ) of recycled urea degraded in the rumen. The permeability of the rumen wall to urea was also significantly increased in sheep given the flaked barley diet (diet A $1.35 \mathrm{~g} \mathrm{~N} / \mathrm{d}$, diet B $2.45 \mathrm{~g} \mathrm{~N} / \mathrm{d}$ ).

7. A model of urea metabolism in sheep given each diet is described, and the mechanisms by which flaked barley inclusion increased urea recycling to the rumen and the efficiency of dietary $\mathrm{N}$ utilization are discussed.

The recycling of urea to the digestive tract of ruminants and its degradation to provide ammonia for microbial metabolism has been proposed as a mechanism whereby ruminants conserve dietary nitrogen during periods of protein deprivation (Houpt, 1970). However, studies using isotope dilution techniques to measure the entry of urea into the digestive tract of sheep have shown that for roughage diets (high and low protein), urea recycling to the rumen was only a small proportion of total degradation, most of which occurred in the lower digestive tract (Nolan \& Leng, 1972, Nolan et al. 1976; MacRae et al. 1977; Norton et al. 1978). The amounts of urea recycled to the rumen of sheep given these diets could

Present addresses: * Department of Agriculture, University of Queensland, St Lucia, Queensland 4067, Australia. $\dagger$ Department of Animal Science and Production, University of Western Australia, Nedlands, Western Australia 6009, Australia. 
be accounted for by salivary urea secretion alone, with apparently little urea entering across the rumen wall.

More recently, Potthast et al. (1977) have reported that the addition of sucrose to a protein-free diet greatly increased the rate of urea entry into the rumen fluid of sheep. Kennedy (1980) also demonstrated a similar effect of sucrose on urea recycling in cattle given low protein roughages, and concluded from this and earlier studies (Kennedy \& Milligan, 1978) that the stimulus to urea entry into the rumen was associated with increased rates of organic matter digestion in the rumen and decreased rumen ammonia concentrations. However, there is no information on the relative significance of salivary secretion and transmural transport as the agents of increased urea recycling to the rumen.

These observations may have significance in the practical feeding of ruminants since the inclusion of concentrates in a roughage diet would not only increase digestible energy intake but also induce an additional flow of endogenous $\mathrm{N}$ into the rumen; on a low protein forage diet such $\mathrm{N}$ might be essential to achieve effective fermentation (McMeniman et al. 1976). Cocimano \& Leng (1967) found that wheat added to a roughage diet increased the rate of urea degradation in the digestive tract, although it is not known what proportion of this degradation occurred in the rumen.

The following experiment was designed to determine whether the addition of a readily fermentable carbohydrate (flaked barley) to a pelleted-grass diet increased the rate of urea recycling to the rumen, and to investigate the quantitative significance of saliva and rumen wall transport as routes of urea entry into the rumen under different dietary regimes.

\section{MATERIALS AND METHODS}

\section{Animals, diets and experimental design}

Three Scottish Blackface wethers $(35-40 \mathrm{~kg} ; 18$ months old), fitted with rumen and oesophageal cannulas were used. Oesophageal fistulation was performed 2 months before the study (Van Dyne \& Torell, 1964) and close fitting split-rubber cannulas were used to ensure minimum leakage. The sheep were held in individual metabolism cages and fed from an hourly feeding machine. Two experimental diets were used. In the first experiment (diet A), each sheep was offered $1000 \mathrm{~g}$ (air-dry basis) pelleted-grass cubes daily ( $889 \mathrm{~g}$ dry matter (DM) $/ \mathrm{kg}$ air-dry food; $896 \mathrm{~g}$ organic matter (OM) and $24.8 \mathrm{~g} \mathrm{~N} / \mathrm{kg} \mathrm{DM}$ ). The second experiment immediately followed the first, and the diet offered (diet B) was $700 \mathrm{~g}$ (air-dry basis) pelleted-grass cubes ( $890 \mathrm{~g} \mathrm{DM} / \mathrm{kg}$ air-dry food; $894 \mathrm{~g}$ OM and $24.4 \mathrm{~g} \mathrm{~N} / \mathrm{kg} \mathrm{DM}$ ) and $300 \mathrm{~g}$ (air-dry basis) flaked barley (871 g DM/kg air-dry feed; $977 \mathrm{~g} \mathrm{OM}$ and $17 \cdot 1 \mathrm{~g} \mathrm{~N} / \mathrm{kg} \mathrm{DM}$ ). All feed offered was consumed and drinking water was continuously available.

\section{Experimental procedure}

In both experiments, a 3-week adaptation period was followed by a 1-week experimental period during which isotope tracer experiments and a balance were conducted. Faeces were collected daily, subsampled and frozen until analysis. Urine was collected by aspiration from rubber belly tanks into flasks containing glacial acetic acid as preservative, and after subsampling was stored frozen until analysis.

Intravenous and intraruminal tracer infusions. Sheep were prepared with catheters in both jugular veins $17 \mathrm{~h}$ prior to the commencement of isotope infusion. A sterile saline solution ( $9 \mathrm{~g}$ sodium chloride $/ 1)$ containing $\left[{ }^{14} \mathrm{C}\right]$ urea $(0.10 \mu \mathrm{Ci} / \mathrm{ml} ; 0.8 \mu \mathrm{mol} / \mathrm{ml} ; 0.3 \mathrm{ml} / \mathrm{min}$ ) was then continuously infused intravenously for $16-22 \mathrm{~h}$, and this infusion was immediately followed by a continuous intravenous infusion of a sterile saline solution containing $\mathrm{NaH}^{14} \mathrm{CO}_{3}(0.13 \mu \mathrm{Ci} / \mathrm{ml} ; 1.2 \mu \mathrm{mol} / \mathrm{ml} ; 0.3 \mathrm{ml} / \mathrm{min})$ which was also maintained for $16-22$ $\mathrm{h}$. At the end of this period, both jugular catheters were removed, and an intraruminal 
infusion of $\mathrm{NaH}^{14} \mathrm{CO}_{3}(0.13 \mu \mathrm{Ci} / \mathrm{ml} ; 1.2 \mu \mathrm{mol} / \mathrm{ml} ; 0.3 \mathrm{ml} / \mathrm{min})$ in distilled water maintained for a further $24 \mathrm{~h}$. In the final $8 \mathrm{~h}$ of each infusion period, samples of blood (by venepuncture), rumen fluid and saliva were taken hourly. Rumen fluid samples were collected by syringe from an intraruminal sampling probe covered by nylon gauze to strain out large food particles. Rumen fluid was immediately subsampled in duplicate as follows: $1 \mathrm{ml}$ for bicarbonate determination, $1 \mathrm{ml}$ for ${ }^{51} \mathrm{Cr}$-EDTA estimation, $10 \mathrm{ml}$ diluted with 10 $\mathrm{ml} 0.2 \mathrm{M}$ hydrochloric acid for ammonia determination, $4 \mathrm{ml}$ added to $1 \mathrm{ml}$ of a protein precipitant (metaphosphoric acid) for volatile fatty acid (VFA) analysis, and $\mathrm{pH}$ and osmolality immediately determined on the remaining sample. Blood was collected into heparinized syringes and after removal of a portion for bicarbonate determination, placed in heparinized tubes and centrifuged at $1500 \mathrm{~g}$ for $20 \mathrm{~min}$. Plasma was stored at $-20^{\circ}$ until analysis.

Oral infusions of ${ }^{51} \mathrm{Cr}$-EDTA and saliva sampling. Throughout the previous tracer infusion experiments, a continuous infusion of a solution containing ${ }^{51} \mathrm{Cr}-\mathrm{EDTA}(0.05 \mu \mathrm{Ci} / \mathrm{ml}$; $0.3 \mathrm{ml} / \mathrm{min}$ ) was delivered into the mouth of each sheep by a ' $\mathrm{J}$ '-shaped stainless steel probe which fitted comfortably into one corner of the mouth. The tube was held in position by attachment to a head halter, and a sleeve of silastic tubing covering the lower part of the tube prevented irritation and directed the infusate deep into the buccal cavity. All sheep easily tolerated this apparatus and there was no detectable loss of infusate during any experiment. For the calculation of rumen dilution rate, it was assumed that all oral infusate entered the rumen. Mixed saliva secretions were collected directly from the oesophageal fistula at hourly intervals (15-30 min after food) by placing the mouth of a plastic container into the oesophageal lumen through the fistula. Approximately $30 \mathrm{ml}$ mixed saliva could be collected in 2-4 min by this method without discomfort to the sheep. At the end of each sampling period, the oesophageal cannula was replaced and secured against leakage by padding with surgical lint. When diet $\mathbf{B}$ was fed, saliva was also collected directly from the mouth by a suction probe for comparison with those samples collected 10 min earlier from the oesophagus. The rate of swallowing before and during collection from both sites appeared to be the same for each sheep. After collection, saliva was immediately subsampled for bicarbonate determination $(0.1 \mathrm{ml})$ and a further portion protein-precipitated by the method described for blood (see below) to inhibit any urease action that may have been present. The remaining sample was acidified with $\mathrm{HCl}$ and stored at $-20^{\circ}$ until analysis.

\section{Analytical methods}

Urea in blood, saliva and urine was determined by the diacetyl monoxime reaction. Protein was precipitated from blood and saliva samples $(4 \mathrm{ml})$ by the successive addition of $8 \mathrm{ml}$ distilled water, $4 \mathrm{ml} \mathrm{0.25} \mathrm{M}$-barium hydroxide and $4 \mathrm{ml} 0.50 \mathrm{M}$-zinc sulphate and aliquots of the carbon dioxide-free supernatant fraction were taken for urea and radioactivity determinations.

The concentrations and specific radioactivities $(S R)$ of blood, rumen fluid and salivary bicarbonate were determined by a modification of the method of Hinks et al. (1966). The sample was placed in a small glass vial suspended inside a scintillation vial containing $1 \mathrm{ml}$ $\mathrm{Ba}(\mathrm{OH})_{2}$ thymolphthalein solution $\left(5 \mathrm{~g}\right.$ thymolphthalein $\left./ 10 \cdot 045 \mathrm{M}-\mathrm{Ba}(\mathrm{OH})_{2}\right)$. Sample $\mathrm{CO}_{2}$ was released by injecting. $0.2 \mathrm{ml} 2 \mathrm{M}$-sulphuric acid through a rubber septum in the air-tight lid of the scintillation vial. After $24 \mathrm{~h}$, residual $\mathrm{Ba}(\mathrm{OH})_{2}$ was titrated with $0 \cdot 168 \mathrm{M}-\mathrm{HCl}$ and the bicarbonate $\left(\mathrm{CO}_{2}\right.$ and $\left.\mathrm{HCO}_{3}^{-}\right)$concentration in the sample calculated. The $\mathrm{BaCO}_{3}$ formed was dissolved by addition of $0.3 \mathrm{ml} 10 \% \mathrm{Na}_{2}$ EDTA in $1 \mathrm{M}$-Tris buffer (pH 9) and distilled water added to constant volume $(2 \mathrm{ml})$.

After addition of scintillant (NE260; Nuclear Enterprises, Sighthill, Edinburgh), radioactivity in both urea and bicarbonate was determined in a Beckman LS-8100 liquid 
scintillation counter. As a standard $n$ - $\left[{ }^{14} \mathrm{C}\right]$ hexadecane was used to correct for different counting efficiencies between and within counting systems. ${ }^{51} \mathrm{Cr}$-EDTA acitivity in saliva and rumen fluid was determined in an automated gamma counter.

Ammonia in rumen fluid was determined by steam-distillation and titration. The concentration of VFA and their proportions in rumen fluid were measured on a Pye 204 gas-liquid chromatograph using crotonic acid as an internal standard (Cottyn \& Boucque 1968). Osmolality of strained rumen fluid was measured on an Advanced Laboratory Osmometer (model 36: Advanced Instruments Inc., Massachussets). Values obtained were corrected for deviation from ideal behaviour by use of known standards. A digital $\mathrm{pH}$ meter was used to determine $\mathrm{pH}$ in rumen fluid within 2 min of sample collection. Total $\mathrm{N}$ and non-protein- $\mathrm{N}$ in saliva were determined by a micro-Kjeldahl method. Protein in saliva was precipitated by addition of an equal volume of trichloroacetic acid $(100 \mathrm{~g} / 1)$ and $\alpha$-amino-N and uric acid-N were estimated by the methods described by Henry et al. (1974). Neither creatinine nor ammonia were detected in significant quantities in any saliva samples analysed. Total $\mathrm{N}$ in food, faeces and urine was determined by the Kjeldahl method, ash by incineration in a muffle furnace at $550^{\circ}$ for $24 \mathrm{~h}$, and DM by drying at $100^{\circ}$ for $24 \mathrm{~h}$.

\section{Calculations}

The irreversible loss of urea from blood, and of bicarbonate- $\mathrm{C}$ from blood and rumen fluid was calculated from the plateau $S R$ of $\mathrm{C}$ in the infused pool and the isotope infusion rate during each study (White et al. 1969). The contribution of the primary (infused) pool (blood or rumen fluid) to the secondary pool (rumen fluid or blood) was determined from the inverse ratio of plateau $S R$ in each of the respective pools during the infusion period. The rate of urea degradation in the digestive tract was calculated as the difference between urea synthesis rate and urinary urea excretion. The model shown in Fig. 1 was used to describe the flow of $\mathbf{C}$ between the pools studied, and the quantitative transfer rates of $\mathrm{C}$ were calculated by the methods described by Nolan et al. (1976). It was assumed that all blood urea- $\mathrm{C}$ was derived from blood bicarbonate and that rumen fluid bicarbonate-C can enter urea-C only from blood bicarbonate-C.

The rate of saliva secretion was estimated as follows:

$$
\text { secretion rate }(\mathrm{ml} / \mathrm{min})=\frac{I}{S R_{\text {sal }}},
$$

where $I$ is the infusion rate of ${ }^{51} \mathrm{Cr}$-EDTA (counts/min per $\mathrm{ml}$ ) and $S R_{\mathrm{sal}}$ is the specific radioactivity of saliva (counts/min per $\mathrm{ml}$ saliva).

The calculated secretion rates were corrected for the small additions of infusate $(0.3 \mathrm{ml} / \mathrm{min})$ and the mean secretion rate for each sheep in each period determined from the average $S R$ of samples collected in that period. The validity of this technique depends on the assumption that the orally infused ${ }^{51} \mathrm{Cr}$-EDTA solution was completely mixed with all salivary secretions at the point of sampling in the mid-oesophagus. It was also assumed that on the hourly feeding regimen, the rate of saliva secretion was little affected by feeding activity.

\section{Statistical analysis}

Where appropriate, analysis of variance was used to test for the significance of differences between sheep, between sampling periods and between diets. When only one measurement (e.g. balance values or isotope dilution measurements) was taken on each sheep during each dietary regimen, the significance of differences between means was determined by a Student's $t$ test. 


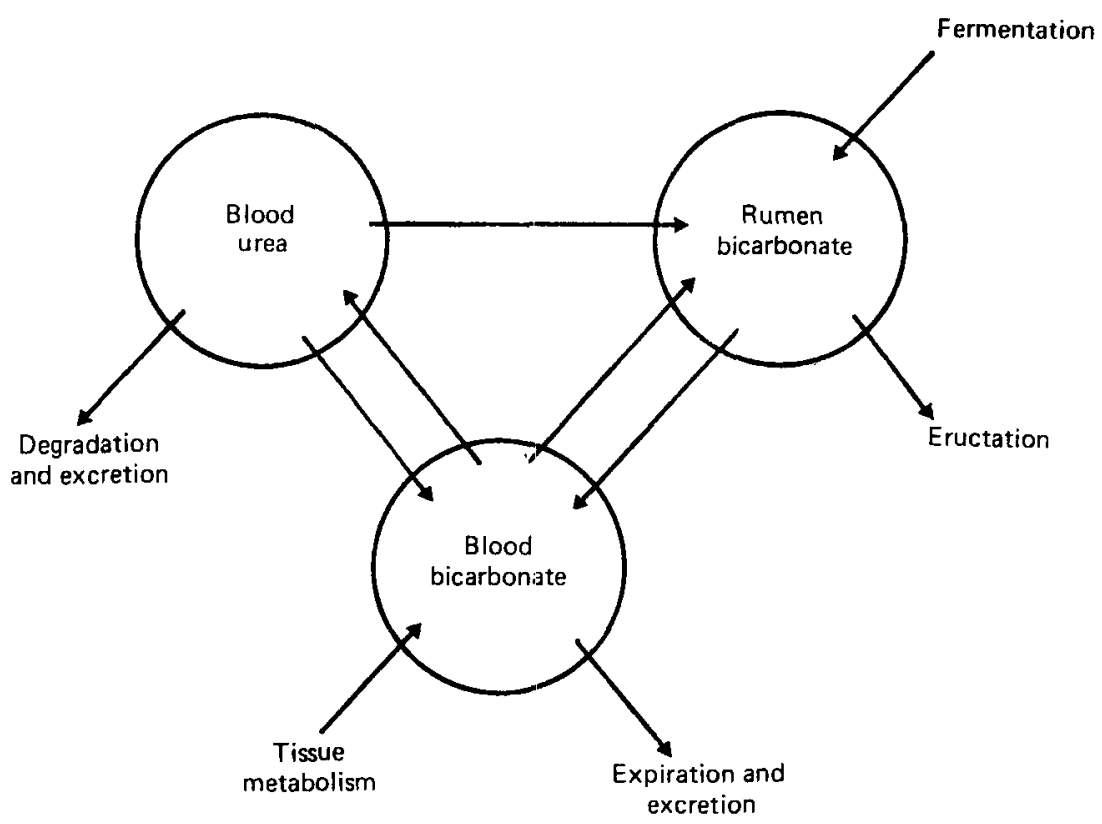

Fig. 1. The model of carbon flow used to determine quantitive transfer rates between blood bicarbonate, rumen bicarbonate and urea-C pools.

RESULTS

Digestion and utilization of dietary $N$ and organic matter

Table 1 shows mean values, with their standard errors, for the digestibility and digestible intake of dietary OM and $\mathrm{N}$, and for the excretion of $\mathrm{N}$ in urine and faeces of sheep given both diets. The inclusion of $300 \mathrm{~g}$ flaked barley $/ \mathrm{kg}$ in the pelleted-grass diet significantly $(P<0.05)$ increased digestible om intake and decreased apparently digested $\mathrm{N}$ intake (diet A $14.6 \mathrm{~g} \mathrm{~N} / \mathrm{d}$, diet $\mathrm{B} 13.7 \mathrm{~g} \mathrm{~N} / \mathrm{d}$ ). Although sheep given diet $\mathrm{B}$ consumed less $\mathrm{N}$ than those on $\operatorname{diet} \mathrm{A}$, they excreted much less $\mathrm{N}$ in both urine and faeces, and consequently retained significantly $(P<0.01)$ greater amounts of $\mathrm{N}$ in their tissues. The efficiency of use of apparently digested $\mathrm{N}$ for tissue retention was thus significantly $(P<0.05)$ increased when flaked barley was included in the diet.

\section{The effect of diet on the composition of rumen fluid}

Rumen fluid samples were collected from each sheep during three separate periods (isotope-infusion periods) of each feeding regimen. Analysis of variance showed that there were no significant differences between either sheep or periods within diets for any of the measurements taken, and it was concluded that steady-state conditions prevailed throughout each dietary regimen. Table 2 shows mean values, with standard errors for the concentrations of VFA (total and individual proportions) and ammonia in rumen fluid, for $\mathrm{pH}$, osmolality, water intake, rumen fluid dilution rate and rumen fluid turnover. The diet containing flaked barley (diet B) significantly $(P<0.01)$ increased butyric acid concentrations and decreased the concentrations of the other, mostly branched-chain VFA and $\mathrm{pH}$ of rumen fluid.

\section{Effects of diet on saliva secretion and composition}

The practical difficulties associated with the use of oesophageally-fistulated animals prompted a comparison between saliva samples collected from the mouth by suction with 
Table 1. Mean values for the digestibility and utilization of organic matter and nitrogen by sheep given diets of pelleted-grass cubes (diet A) and pelleted-grass cubes with $300 \mathrm{~g}$ flaked barley/kg (diet B)

\begin{tabular}{|c|c|c|c|c|c|c|c|}
\hline \multirow[b]{2}{*}{ Diet } & \multicolumn{3}{|c|}{ Organic matter } & \multicolumn{4}{|c|}{ Nitrogen } \\
\hline & $\begin{array}{l}\text { Apparent } \\
\text { digestibility }\end{array}$ & $\begin{array}{c}\text { Digestible } \\
\text { intake } \\
(\mathrm{g} / \mathrm{d})\end{array}$ & $\begin{array}{l}\text { Apparent } \\
\text { digestibility }\end{array}$ & $\begin{array}{l}\text { Faecal } \\
\text { excretion } \\
(\mathrm{g} / \mathrm{d})\end{array}$ & $\begin{array}{l}\text { Urinary } \\
\text { excretion } \\
(\mathrm{g} / \mathrm{d})\end{array}$ & $\begin{array}{c}\stackrel{N}{N} \\
\text { balance } \\
(\mathrm{g} / \mathrm{d})\end{array}$ & $\begin{array}{l}\text { Proportion of } \\
\text { digested N } \\
\text { retained }\end{array}$ \\
\hline A & 0.670 & 533 & 0.666 & $7 \cdot 4$ & $13 \cdot 3$ & $1 \cdot 3$ & 0.089 \\
\hline B & 0.739 & 601 & 0.693 & $6 \cdot 0$ & 7.9 & $5 \cdot 7$ & 0.421 \\
\hline $\mathrm{SE}$ of mean & $0.010^{*}$ & $9 * *$ & 0.006 & $0.04 * *$ & $0 \cdot 3^{* *}$ & $0.4^{* *}$ & $0.038^{* * *}$ \\
\hline
\end{tabular}

Statistical significance of difference between diets ${ }^{*} P<0.05,{ }^{* *} P<0.01$.

Table 2. Mean values for the concentrations of total volatile fatty acids and their proportions, ammonia concentration, $p H$, osmolality and fluid kinetics in the rumen of sheep given pelleted-grass cubes (diet $A$ ) and pelleted-grass cubes with $300 \mathrm{~g}$ flaked barley/ $\mathrm{kg}$ (diet B)

\begin{tabular}{lccc}
\hline \hline Diet ... & A & B & SE of mean \\
\hline Total VFA (mmol/l) & 90 & 88 & 4 \\
Individual VFA (mmol/mol total VFA) & & & \\
$\quad$ Acetic acid & 669 & 663 & 5 \\
Propionic acid & 200 & 191 & 10 \\
Butyric acid & 88 & 113 & $7^{*}$ \\
Others & 43 & 33 & 4 \\
Ammonia (mg N/l) & 124 & 124 & 9 \\
pH & 6.43 & 5.99 & $0.03^{* *}$ \\
Osmolality (mosmol/kg) & 291 & 278 & 14 \\
Water intake (l/d) & $2 \cdot 97$ & 2.77 & $0 \cdot 14$ \\
Rumen fluid dilution (/h) & 0.0602 & 0.0610 & 0.005 \\
Rumen fluid turnover (l/d) & 11.71 & 10.71 & 0.41 \\
\hline
\end{tabular}

Statistical significance of difference between diets ${ }^{*} P<0.05,{ }^{*} P<0.01$.

those collected at a similar time from the oesophageal fistula. The results from this study on sheep given diet B are shown in Table 3. The estimates of salivary flow-rate by the isotope dilution technique were similar for samples taken from the mouth and oesophagus, indicating complete mixing of the isotope with salivary secretions before swallowing. However, saliva taken from the mouth was significantly $(P<0.05)$ higher in total and protein-N content, and significantly $(P<0.05)$ lower in urea and bicarbonate concentrations. It was concluded that secretions sampled from the mouth were not representative of those swallowed, and all subsequent samples were collected from the oesophageal fistula.

Table 4 gives mean values, with their standard errors, for the estimated secretion rates and composition of mixed saliva from sheep given the two diets. Analysis of variance showed that there were no significant differences between either sheep or sampling periods within diets for any of the measurements taken. However, sheep given the pelleted-grass diet (diet A) had significantly higher $(P<0.01)$ saliva secretion rates than did sheep given diet $B$. The coefficients of variation associated with the estimate of salivary flow from the three sheep on each diet were 12.3 and $11.5 \%$ for diets A and B respectively. There was no 


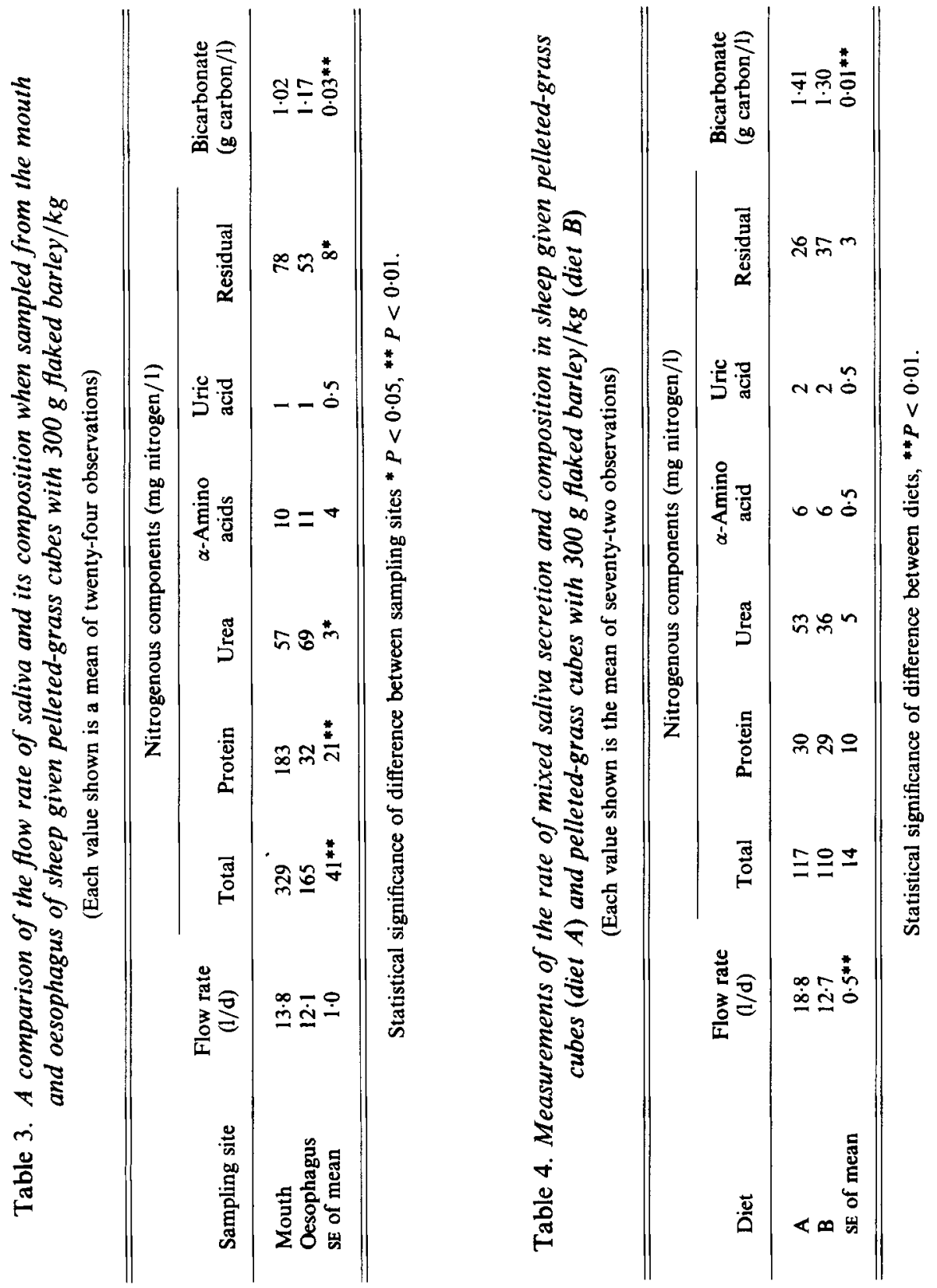


Table 5. Some measurements of bicarbonate metabolism in blood and rumen fluid of sheep given pelleted-grass cubes (diet $A$ ) and pelleted-grass cubes with $300 \mathrm{~g}$ flaked barley/kg (diet $B$ )

\begin{tabular}{|c|c|c|c|}
\hline Diet & A & B & SE of mean \\
\hline \multicolumn{4}{|l|}{ Rumen fluid bicarbonate } \\
\hline Irreversible loss $(\mathrm{g} \mathrm{C} / \mathrm{d})$ & $106 \cdot 2$ & $219 \cdot 0$ & $3 \cdot 6^{* *}$ \\
\hline Bicarbonate concentration $(\mathrm{g} \mathrm{C} / \mathrm{l})$ & 0.392 & 0.270 & $0.023^{* *}$ \\
\hline \multicolumn{4}{|c|}{ Percentage of ruminal bicarbonate from } \\
\hline Blood bicarbonate & 37.9 & $36 \cdot 0$ & $2 \cdot 5$ \\
\hline Blood urea & $1 \cdot 20$ & 0.75 & $0 \cdot 010^{* *}$ \\
\hline \multicolumn{4}{|l|}{ Blood bicarbonate } \\
\hline Irreversible loss ( $\mathrm{g} \mathrm{C} / \mathrm{d}$ ) & $262 \cdot 7$ & $272 \cdot 1$ & $9 \cdot 7$ \\
\hline Bicarbonate concentration $(\mathrm{g} \mathrm{C} / \mathrm{l})$ & 0.303 & $0 \cdot 280$ & $0.006^{*}$ \\
\hline \multicolumn{4}{|l|}{ Percentage of blood bicarbonate from } \\
\hline Rumen bicarbonate & $40 \cdot 0$ & $40 \cdot 9$ & $2 \cdot 6$ \\
\hline Blood urea & 1.05 & 0.64 & $0.010^{*}$ \\
\hline
\end{tabular}

Statistical significance of difference between diets ${ }^{*} P<0.05,{ }^{* *} P<0.01$.

significant effect of diet on the concentrations of total N, protein-N, $\alpha$-amino acid-N, uric acid-N or bicarbonate in mixed saliva.

Although salivary urea concentration was significantly $(P<0.05)$ correlated with both plasma urea concentration and saliva secretion rate, multiple regression analysis showed that variation in plasma urea accounted for over $98 \%$ of the variation in salivary urea concentration and that the addition of secretion rate as a second variable did not significantly reduce error variance. An analysis of covariance of the relationship between salivary urea and plasma urea concentrations for sheep given both diets showed no significant differences between diets after adjustment to a common mean. The combined regression equation $(n$ 18), with residual standard deviation (RSD) and correlation coefficient $(r)$ was:

$$
S=0.3784 P+11 \cdot 8(\mathrm{RSD} \pm 8 \cdot 1, r 0.80)
$$

where $S$ is the salivary urea concentration $(\mathrm{mg} \mathrm{N} / \mathrm{l})$ and $P$ is the plasma urea concentration (mg $\mathrm{N} / \mathrm{l}$ ). The equation indicates that as plasma urea concentration increased, the ratio, salivary : plasma urea concentration, decreased.

A significant percentage (22-34) of total $\mathrm{N}$ in saliva was still unaccounted for after analysis for the known major nitrogenous constituents. Both creatinine and ammonia concentrations were negligible, and the nature of the additional $\mathrm{N}$ is unknown.

\section{Bicarbonate metabolism in blood and rumen fuid}

Table 5 shows mean values, with their standard errors, for the irreversible loss of bicarbonate-C from the rumen fluid and blood bicarbonate pools, for the proportions of rumen fluid and blood bicarbonate pools derived from plasma urea, blood and rumen fluid bicarbonate pools and for the concentrations of bicarbonate in blood and rumen fluid.

Sheep given diet $\mathrm{A}$ had significantly $(P<0.05)$ higher bicarbonate concentrations in both blood and rumen fluid, but significantly $(P<0.01)$ lower rates of irreversible loss of bicarbonate from rumen fluid than did sheep given diet $B$. The irreversible loss of bicarbonate from blood was not significantly affected by diet. The percentage of blood bicarbonate derived from blood urea represented a small but significant recycling of $\mathrm{C}$ from urea degradation in the digestive tract back to urea through the blood bicarbonate pool. During each isotope infusion, the $S R$ of salivary bicarbonate and salivary urea were determined 
Table 6. Mean values for the rates of synthesis, degradation and excretion of urea in sheep given pelleted-grass cubes (diet A) and pelleted grass cubes with $300 \mathrm{~g}$ flaked barley/kg (diet B)

\begin{tabular}{|c|c|c|c|}
\hline Diet & A & B & SE of mean \\
\hline Plasma urea concentration (mg N/l) & 111 & 63 & $4 * \bullet$ \\
\hline Urea synthesis $(\mathrm{g} \mathrm{N} / \mathrm{d})$ & $20 \cdot 0$ & $9 \cdot 7$ & $0 \cdot 6^{* *}$ \\
\hline Urinary urea excretion (g N/d) & $10 \cdot 2$ & $4 \cdot 4$ & $0 \cdot 8^{* *}$ \\
\hline \multicolumn{4}{|l|}{ Degradation in total digestive tract ${ }^{\dagger}$} \\
\hline $\mathrm{g} \mathrm{N} / \mathrm{d}$ & 9.8 & $5 \cdot 3$ & $0.5^{* *}$ \\
\hline Percentage of urea synthesis & 49 & 54 & 5 \\
\hline \multicolumn{4}{|l|}{ Degradation in the rument } \\
\hline $\mathrm{g} \mathrm{N} / \mathrm{d}$ & $2 \cdot 3$ & 3.0 & $0.2^{* *}$ \\
\hline Percentage of total degradation & 24 & 57 & $12^{*}$ \\
\hline \multicolumn{4}{|l|}{ Degradation in lower digestive tract§ } \\
\hline $\begin{array}{l}\mathrm{g} N / \mathrm{d} \\
\text { Percentage of total degradation }\end{array}$ & $7 \cdot 7 \cdot 5$ & $\begin{array}{l}2 \cdot 3 \\
43\end{array}$ & $\begin{array}{l}0.9^{* *} \\
12^{*}\end{array}$ \\
\hline
\end{tabular}

Statistical significance between diets $* P<0.05, * * P<0.01$.

$\dagger$ Urea synthesis - urinary urea excretion.

$\ddagger$ Determined by solution of pathways shown in Fig. 1.

$\$$ Total urea degradation - urea degradation in the rumen.

and found not to be significantly different from the $S R$ of blood bicarbonate during the same infusion. This observation validates the assumptions made in the model described later (Fig. 2), i.e. that all blood urea-C is derived from blood bicarbonate and that blood urea and bicarbonate are the only sources of these constituents in saliva.

\section{The effects of diet on urea synthesis, degradation and excretion}

Mean values, with their standard errors, for urea synthesis, the degradation of urea in the rumen and lower digestive tract, urinary urea excretion and plasma urea concentrations in sheep given diets $A$ and $B$ are shown in Table 6.

Significant recycling of urea-C through the digestive tract to blood bicarbonate resulted in the irreversible loss of urea underestimating total urea synthesis by 1.0 and $0.6 \%$ for sheep given diets $\mathrm{A}$ and $\mathrm{B}$ respectively. Although $\mathrm{N}$ intakes were reasonably comparable, sheep given diet $\mathrm{B}$ had significantly $(P<0.05)$ lower rates of urea synthesis and lower plasma urea concentrations than did sheep given diet $A$. Although a similar proportion of the urea synthesized was degraded in the whole digestive tract of sheep given both diets, the distribution of degradation between the rumen and lower tract was significantly affected by diet. Sheep given diet B (flaked barley) recycled smaller quantities of urea to the whole digestive tract, but a significantly $(P<0.05)$ greater amount and proportion of total degradation occurred in the rumen of these sheep when compared with sheep given diet A. Conversely, in sheep given diet A, $76 \%$ of the total urea degradation occurred in the lower digestive tract, whereas in sheep given diet $\mathrm{B}$ only $43 \%$ of the total was degraded in the same site.

\section{Models of urea metabolism in sheep given diets $A$ and $B$}

The results presented in Tables 3,5 and 6 were used to synthesize a model of urea-C flow to its various sinks of degradation and excretion for sheep given the two different diets. The models constructed from this information are shown in Fig. 2, and present a more comprehensive view of the effect of diet on urea metabolism than do the various individual 

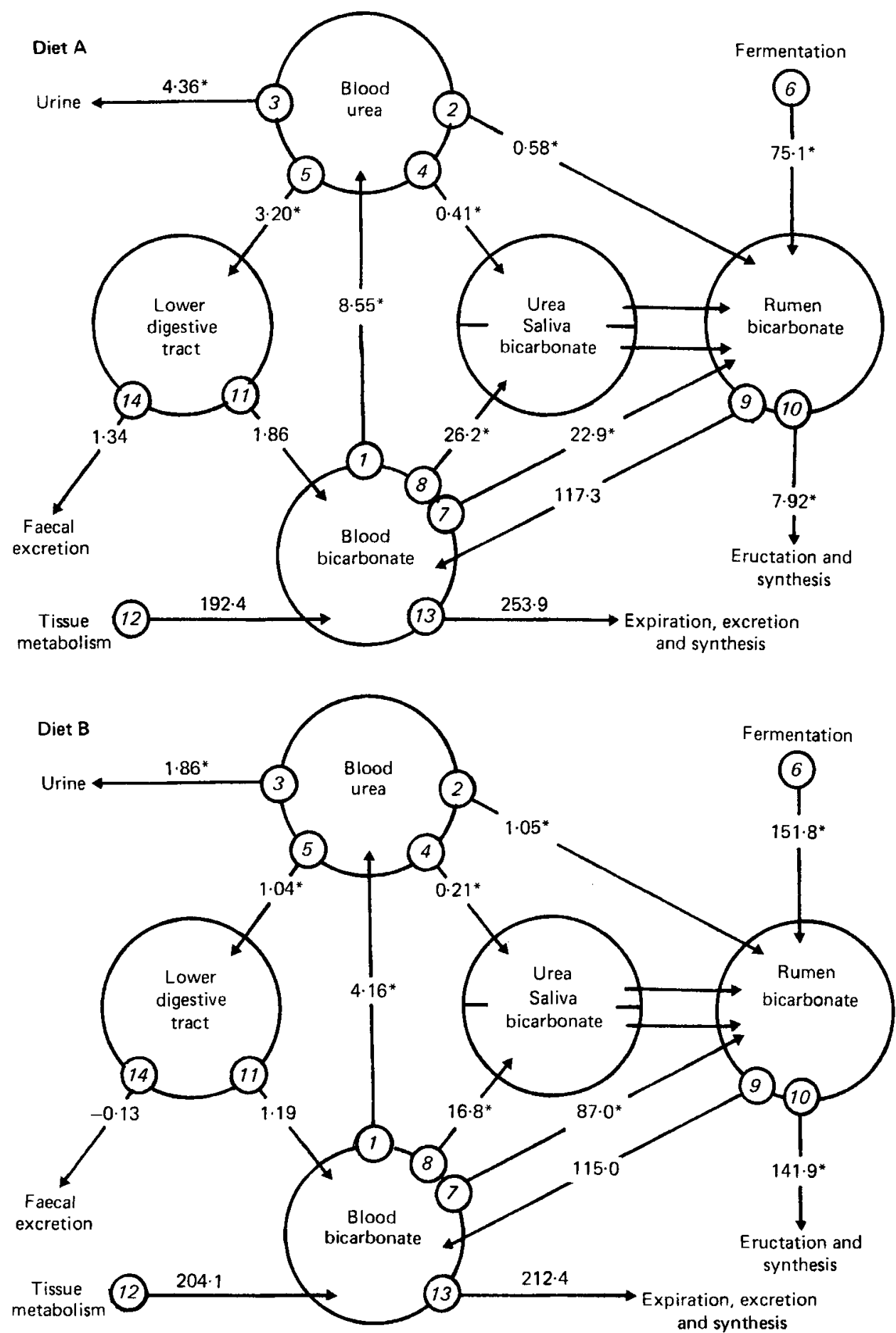

Fig. 2. Models of carbon transfer $(\mathrm{g} \mathrm{C} / \mathrm{d})$ between blood urea, blood bicarbonate, rumen fluid bicarbonate, lower digestive tract bicarbonate and salivary urea and bicarbonate pools for sheep given pelleted-grass cubes (diet A) and pelleted-grass cubes with $300 \mathrm{~g}$ flaked barley $/ \mathrm{kg}$ (diet B). Each value shown is a mean for three sheep. Significant differences $(P<0.05)$ in $\mathrm{C}$ transfer between diets for each pathway are indicated thus $(*)$. 
pathways previously described. The quantitive transfer of urea from blood to rumen fluid through the rumen wall (pathway 2) was calculated as the difference between total urea entry into the rumen and that contributed by salivary secretions. The passage of blood bicarbonate across the rumen wall (pathway 7) was calculated as the difference between total bicarbonate entry into rumen fluid and that contributed by salivary secretions. Faecal excretion of blood urea- $\mathrm{C}$ was calculated as the difference between urea-C degraded in the lower digestive tract (pathway 5) and urea-C recycled from the lower digestive tract to blood bicarbonate (pathway 11). For sheep given diet $\mathrm{B}$, a complete solution to the $\mathrm{C}$ flow model resulted in a small negative value for urea- $C$ excreted in faeces. This value was not significantly different from zero, and indicated that the major route of urea-C excretion for sheep on this diet was in urine.

Sheep given diet B ( $300 \mathrm{~g}$ flaked barley $/ \mathrm{kg}$ ) not only recycled a greater amount of urea to rumen fluid than did sheep given diet $A$, but also recycled a significantly greater amount through the rumen wall. Sheep given diet $A$ transferred $1.35 \mathrm{~g} \mathrm{~N} / \mathrm{d}$ across the rumen wall, representing $59 \%$ of the total urea recycled to the rumen, whereas sheep given diet $\mathrm{B}$ recycled $2.45 \mathrm{~g} \mathrm{~N} / \mathrm{d}$ through the rumen wall representing $83 \%$ of the total urea entry into the rumen. The clearance rate of blood urea through the rumen wall was $12.21 / \mathrm{d}$ for sheep given diet $A$ and $38.9 \mathrm{l} / \mathrm{d}$ for sheep given diet $\mathrm{B}$, indicating a major change in the permeability of the rumen epithelium to urea entry into the rumen.

Diet also had a significant effect on the total flux of bicarbonate through the rumen which increased by $106 \%$ when flaked barley was included in the diet. Bicarbonate arising from fermentation contributed significantly to this increased flux, as did a greater transfer of blood bicarbonate to rumen fluid across the rumen wall (pathway 7). However, the major route of irreversible loss for sheep given diet $\mathrm{B}$ was directly from rumen fluid (pathway 10 ), whereas the major route of bicarbonate loss from the rumen fluid of sheep given diet $A$ was through transfer to blood bicarbonate (pathway 9). Similar amounts of bicarbonate were transferred by this route in sheep given both diets.

\section{DISCUSSION}

\section{Dietary nitrogen utilization and rumen fermentation}

The addition of readily fermentable carbohydrate such as barley or maize to ruminant diets usually has the effect of increasing digestible om intake and decreasing the pH (Ørskov \& Fraser, 1975) and ammonia concentrations in rumen fluid (Oldham et al. 1973; Chamberlain et al. 1980). The effects of varying forage:concentrate ratios on VFA concentrations in the rumen fluid is less clear (Sutton, 1979). In some instances, high propionic acid levels were produced and in other animals on the same diet, high levels of butyric acid were produced. Low propionate fermentations usually have higher ammonia concentrations than do high butyrate fermentation patterns (Ishaque et al. 1971).

In the present study, digestible energy intake was increased by the addition of flaked barley to the pelleted-grass diet, and there was a small but significant rise in butyric acid concentration in rumen fluid and a significant decrease in $\mathrm{pH}$. However, ammonia concentrations were unaffected by flaked barley addition, remaining relatively high on both diets. The major effect of diet modification was a fourfold increase in $\mathrm{N}$ retention, which was almost entirely accounted for by a corresponding decrease in urinary urea excretion.

These results suggest that the inclusion of flaked barley in the diet may have reduced the rate of ammonia absorption from rumen fluid, thereby decreasing urea synthesis and urea excretion in urine. Hogan (1961) has proposed that ammonia absorption from the rumen may be by simple diffusion of unionized ammonia in accordance with its concentration gradient, and since $\mathrm{pH}$ determines the ratio, ammonia:ammonium ion in rumen fluid, ammonia absorption is a $\mathrm{pH}$-dependent process. A decrease in $\mathrm{pH}$ from 6.43 to 5.99 found 
in the present study when flaked barley was included in the diet would have decreased ammonia concentration in rumen fluid by $54 \%$, thereby reducing ammonia absorption to a similar extent. A decrease in the rate of ammonia absorption of this magnitude is supported by the observation that urea synthesis rate decreased by a similar amount $(49 \%)$ during flaked barley feeding.

The additional $\mathrm{N}$ retained $(4.4 \mathrm{~g} \mathrm{~N} / \mathrm{d})$ in the tissues of sheep given the flaked barley diet would have required that an additional $10.5 \mathrm{~g}$ microbial $\mathrm{N}$ be absorbed from the intestines ( 0.80 microbial $\mathrm{N}$ as amino acids, 0.70 efficiency of absorption of amino acids, 0.75 biological value of absorbed amino acids; Agricultural Research Council (1980)). This quantity of $\mathrm{N}$ approximately equals that saved from urea synthesis $(10.2 \mathrm{~g} \mathrm{~N} / \mathrm{d})$ and the additional $\mathrm{N}$ recycled to the rumen $(0.8 \mathrm{~g} \mathrm{~N} / \mathrm{d})$.

However, the incorporation of this additional $\mathrm{N}$ into absorbable protein would require a significant increase in the efficiency of microbial synthesis and/or decrease in dietary protein degradability in the rumen when flaked barley was added to the diet.

In a study with sheep given a high quality dried grass, ground and pelleted or the same grass with $200 \mathrm{~g} / \mathrm{kg}$ DM replaced by rolled barley, Coelho da Silva (1971) observed increments in total and amino acid-N (AA-N) entering the small intestine on the barley supplemented diet despite the reduction in $\mathrm{N}$ intake. Mean values for $\mathrm{N}$ intake, and for $\mathrm{N}$ and AA-N entering the small intestine $(\mathrm{g} / 24 \mathrm{~h})$ were for the grass alone $28 \cdot 7,34 \cdot 1$ and $20 \cdot 2$, and for the grass/barley diet $24.5,30.5$ and 24.4 . The retention of total $N$ was significantly increased by partial replacement of dried grass by barley; mean values for $\mathrm{N}$ retention as a percentage of total $\mathrm{N}$ fed were for the grass alone 18.6 and for the grass/barley diet 43.8 . The latter values are in agreement with the observations recorded in the present experiment, and the studies of Coelho da Silva (1971) do indicate considerably increased entry of AA-N into the small intestine by partial replacement of the dried forage with a cereal. In the present study, the barley was steam-flaked and therefore might well be expected to result in more efficient synthesis of microbial protein in the rumen. Meggison et al. (1979), in studies with Jersey cattle, obtained values for microbial protein synthesis ( $\mathrm{g} \mathrm{N} / \mathrm{kg}$ OM apparently digested in the rumen) of $22.4 \pm 1.29$ for a hay and rolled barley diet and $35 \cdot 7 \pm 1.06$ for a hay and flaked barley diet. Kennedy (1980) found that the addition of sucrose to a roughage diet fed to cattle significantly increased both the apparent digestibility of $\mathrm{OM}$ in the rumen and the efficiency of microbial protein synthesis, effectively doubling the microbial protein available at the intestines for absorption. These major increases in efficiency of dietary $\mathrm{N}$ utilization as a result of adding relatively small amounts of fermentable carbohydrate to the diet require further study.

\section{The effects of diet on saliva secretion and composition}

The estimates of mixed saliva secretion rates in sheep on the two diets were within the range (6-24 l/d) usually reported for sheep (Tribe \& Peel, 1963; Kay, 1966; Clarke \& Reid, 1974) but were considerably higher than estimates from parotid gland cannulas (Kay, 1960; Somers, $1961 a, b$ ) and phosphorus dilution techniques (Hemsley et al. 1975; Kennedy \& Milligan, 1978). The latter technique assumed that saliva sampled from the mouth was similar to that entering the rumen but if, as found in the present experiment, samples from the mouth were not representative of mixed saliva, saliva secretion rate would be underestimated by this technique. The higher secretion rates found in sheep given the pelleted-grass diet may be related to the greater frequency of rumination observed, and the generally high rates of secretion in sheep given both diets may be related to the presence of the infusion probe in the mouth and a stimulation of secretory activity during sampling procedures from the oesophageal fistula.

The composition of mixed saliva collected was similar to that reported by other workers 
(Kay, 1960; Somers, $1961 a$; Kay, 1966) and, with the exception of urea, the concentrations of nitrogenous constituents and bicarbonate were independent of both diet and saliva secretion rate. Although saliva contributed significant amounts of bicarbonate to rumen fluid, the major sources of bicarbonate for buffering action arose from fermentation and from blood by transport across the rumen wall. In sheep given diet A, $21 \%$ of the total bicarbonate entering the rumen was derived from saliva, and for sheep given diet $\mathbf{B}$, only $6.5 \%$ of total ruminal bicarbonate arose from saliva secretion. These observations confirm the views of Ash \& Dobson (1963) and Kay (1966) that salivary bicarbonate secretion alone is inadequate to explain the total buffering action of bicarbonate in rumen fluid.

Salivary secretions added 2.2 and $1.4 \mathrm{~g} \mathrm{~N}$ to the rumen of sheep given diets A and B respectively, increasing total $\mathrm{N}$ input into the rumen by $10 \%$ for diet $\mathrm{A}$ and $7 \%$ for diet B. Protein N represented only a small proportion (0.25) of this additional N. Somers $(1961 b)$ has reported that urea-N in mixed and parotid saliva represented $61-72 \%$ of total $\mathrm{N}$; in the present study, saliva urea- $\mathbf{N}$ formed a much lower proportion of total salivary- $\mathbf{N}$ (33-45\%). At comparable plasma urea concentrations (111 mg N/l), Somers $(1961 b)$ found the ratio of saliva to plasma urea concentration to be 0.58 ; in the present study, a lower ratio was found $(0 \cdot 48)$.

Despite large differences in saliva secretion rates between diets, the clearance rates of urea from blood to saliva were similar $(9 \cdot 0$ and $7 \cdot 3 \mathrm{l} / \mathrm{d}$ for diets A and B respectively) and may suggest that the permeability of the salivary gland to urea is independent of the diet fed. However, irrespective of diet, the quantitative contribution of saliva to the $\mathbf{N}$ economy of the rumen was small compared with the likely effects of $\mathrm{pH}$ on rumen ammonia absorption and an increased efficiency of microbial $\mathrm{N}$ synthesis. It was also apparent that saliva was not the major route by which large additions of urea were made to the rumen during sucrose feeding (Potthast et al. 1977).

\section{Bicarbonate metabolism in rumen fluid and blood}

Bicarbonate production from fermentation (pathway 6, Fig. 2) was doubled when barley was included in the pelleted-grass diet, and the rate of bicarbonate formation in the rumen was significantly greater than that expected from the stoichiometric relationship between estimated VFA and $\mathrm{CO}_{2}$ production rates (Leng, 1973). When similar calculations were applied to the results from other studies of rumen bicarbonate synthesis in sheep (MacRae et al. 1977; Rowe et al. 1978; Nolan \& Stachiw, 1979; MacRae et al. 1979), bicarbonate apparently arising from fermentation also exceeded by a significant margin that expected from stoichiometry. These results suggest that $\mathrm{CO}_{2}$ in rumen fluid arises not only from the anaerobic fermentation of hexoses to VFA, but may also be produced in the formation of lactic acid, from the catabolism of microbial cells, the decarboxylation of dietary amino acids, from aerobic metabolism of VFA in the rumen epithelium and from alternative pathways of carbohydrate degradation to those proposed in stoichiometric calculations.

The routes of irreversible loss of bicarbonate from the rumen were also significantly altered by the inclusion of barley in the diet. Sheep given diet A transferred $89 \%$ of the bicarbonate arising from fermentation to blood, which was then excreted in expired air or urine, whereas the major route of bicarbonate loss for sheep given diet $\mathrm{B}$ was by eructation as gaseous $\mathrm{CO}_{2}$. A partial explanation of these results may be the effects of differing rumen $\mathrm{pH}$ on the relative concentrations of carbonic acid $\left(\mathrm{H}_{2} \mathrm{CO}_{3}\right)$ and bicarbonate $\left(\mathrm{HCO}_{3}{ }^{-}\right)$in rumen fluid and blood as shown in Table 7.

The similarity in $\mathrm{H}_{2} \mathrm{CO}_{3}$ concentrations in the rumen fluid of sheep given both diets suggests that $\mathrm{H}_{2} \mathrm{CO}_{3}$ may be in equilibrium with gaseous $\mathrm{CO}_{2}$ in the rumen. Bicarbonate entering rumen fluid from fermentation of diet $\mathrm{B}$, would rapidly equilibrate with $\mathrm{H}_{2} \mathrm{CO}_{3}$ increasing gas production and hence rate of removal by eructation. The concentration 
Table 7. The effect of rumen $\mathrm{pH}$ on the carbonic acid and bicarbonate concentrations $(\mathrm{mmol} / \mathrm{l})$ in rumen fluid and blood of sheep given pelleted-grass cubes (diet $A$ ) and pelleted-grass cubes with $300 \mathrm{~g}$ flaked barley/ $\mathrm{kg}$ (diet B)

\begin{tabular}{|c|c|c|c|c|}
\hline \multirow[t]{2}{*}{ Diet } & \multicolumn{2}{|c|}{ A } & \multicolumn{2}{|c|}{ B } \\
\hline & Blood & Rumen & Blood & Rumen \\
\hline $\mathrm{pH}$ & 7.4 & 6.43 & $7 \cdot 4$ & 5.99 \\
\hline$\left[\mathrm{H}_{2} \mathrm{CO}_{3}+\mathrm{HCO}_{3}^{-}\right]$ & $25 \cdot 3$ & $32 \cdot 7$ & $23 \cdot 3$ & $22 \cdot 5$ \\
\hline Proportion as $\mathrm{H}_{2} \mathrm{CO}_{3}^{*}$ & $0 \cdot 102$ & 0.505 & $0 \cdot 102$ & 0.745 \\
\hline$\left[\mathrm{H}_{2} \mathrm{CO}_{3}\right]$ & $2 \cdot 6$ & $16 \cdot 5$ & $2 \cdot 4$ & $16 \cdot 8$ \\
\hline$\left[\mathrm{HCO}_{3}^{-}\right]$ & $22 \cdot 7$ & $16 \cdot 2$ & $20 \cdot 9$ & 5.7 \\
\hline
\end{tabular}

* Calculated from the Henderson-Hasselbach equation: $\mathrm{p} K_{a}=\mathrm{pH}+\log _{10} \frac{\left[\mathrm{H}_{2} \mathrm{CO}_{3}\right]}{\left[\mathrm{HCO}_{3}{ }^{-}\right]}$, where $K_{a}=3.5 \times 10^{-7}$.

gradient of $\mathrm{H}_{2} \mathrm{CO}_{3}$ (and $\mathrm{CO}_{2}$ ) favours movement from rumen fluid to blood, and the transit of $\mathrm{H}_{2} \mathrm{CO}_{3}$ through epithelial cells at $\mathrm{pH} 7.4$ would rapidly liberate $\mathrm{H}^{+}$required for VFA absorption with the resultant $\mathrm{HCO}_{3}{ }^{-}$being preferentially returned to rumen liquor (Masson \& Phillipson, 1951; Ash \& Dobson, 1963; Stevens, 1970). The similarity in the $\mathrm{H}_{2} \mathrm{CO}_{3}$ gradient between rumen and blood for sheep on both diets may account for the similar rates of bicarbonate transfer from rumen to blood observed in these sheep. The quantities of bicarbonate flowing to and apparently absorbed from the abomasum were relatively small ( 4.6 and $2.9 \mathrm{~g} \mathrm{C} / \mathrm{d}$ for diets $\mathrm{A}$ and $\mathrm{B}$ respectively) compared with the amounts of bicarbonate absorbed across the rumen wall.

The concentration gradient of $\mathrm{HCO}_{3}{ }^{-}$favours entry of $\mathrm{HCO}_{3}{ }^{-}$into the rumen from blood, and the large differences in transfer rate by this route observed for sheep on the different diets may be related to the threefold difference of $\mathrm{HCO}_{3}{ }^{-}$concentration in rumen fluid. Although further studies of bicarbonate metabolism in sheep are needed to confirm the previously described calculation, $\mathrm{pH}$ does appear to have a significant effect on the quantitative and qualitative metabolism of bicarbonate in the rumen.

\section{The effect of diet on urea degradation in the digestive tract}

The extent and significance of urea recycling to the digestive tract of ruminants has been reviewed recently (Engelhardt et al. 1978; Nolan \& Stachiw, 1979; Kennedy, 1980; Armstrong, 1980) and evidence was presented that urea recycling to the rumen was related to the type of diet fed. The present study confirmed this view, since the inclusion of flaked barley in a pelleted-grass diet increased both the total amount of urea degraded in the rumen and the rate of urea entry across the rumen wall. Engelhardt et al. (1978) have proposed that clearance rate of urea from blood through the rumen wall is a measure of functional permeability of the rumen wall to urea. In our study, the inclusion of flaked barley in the diet increased rumen clearance of urea by $340 \%$, clearly demonstrating a major effect of diet on the permeability of the rumen wall to urea. Kennedy (1980) also found an increased rumen clearance of urea when sucrose was added to roughage diets given to cattle, although in this instance, rumen clearance refers to the permeability of both the salivary glands and rumen wall to urea.

Sheep given both diets secreted urea into the rumen through saliva and across the rumen wall supporting conclusions from studies with in vitro and washed out rumen preparations where significant transport of urea across the rumen wall was observed (Houpt, 1957; 
Simonnet et al. 1957; Houpt, 1970). Total urea transfer from blood to rumen in the present experiment $(2 \cdot 3-3 \cdot 1 \mathrm{~g} \mathrm{~N} / \mathrm{d})$ was higher than that reported for sheep given lucerne or low quality diets (0.6-2.3 g N/d) (Nolan \& Leng, 1972; Nolan et al. 1976; Norton et al. 1978; MacRae et al. 1979; Nolan \& Stachiw, 1979) but considerably lower than recycling rates in sheep given either high intakes of a pelleted Brome-grass diet (7.3-9.6 g N/d; Kennedy $\&$ Milligan, 1978) or diets containing a high proportion of sucrose $(9.5 \mathrm{~g} \mathrm{~N} / \mathrm{d}$; Potthast et al. 1977).

Kennedy (1980) has proposed that urea recycling to the rumen of cattle increased when digestible ом intake increased and/or ruminal ammonia concentrations decreased. In our study, a small increase in digestible om intake $(13 \%)$ resulted in a $35 \%$ increase in the total amount of urea recycled to the rumen, and an even greater increase $(93 \%)$ in the amount of urea transferred across the rumen wall. A more likely stimulus to urea recycling in ruminants given concentrate or sucrose supplements may be the nature of the end-products of their fermentation. Thorlacius et al. (1971) found an increased rate of urea entry into a temporarily isolated bovine rumen when $\mathrm{CO}_{2}$ was bubbled through its contents, and VFA, particularly butyric acid, has been reported to be a potent stimulant of urea entry into the rumen of the llama (Hinderer \& Engelhardt, 1975). In the present experiment, increased urea recycling to the rumen was associated with elevated butyric acid concentrations in rumen liquor and an increased rate of bicarbonate production in the rumen. The specific effects of these metabolites on urea recycling to the rumen are the subject of a following paper (Norton et al. 1982).

Rumen ammonia concentrations have been correlated with urea recycling to the rumen, stimulated recycling apparently occurring when ammonia concentrations are low in rumen fluid (Varady et al. 1967; Thornton, 1970; Kennedy \& Milligan, 1978; Wallace et al. 1979; Kennedy, 1980). In our experiments there was no relationship between rumen ammonia concentrations and the quantity of urea recycled to the rumen; in fact, increased recycling occurred without a change in rumen ammonia concentration and with a decreased rate of urea synthesis in the body. Although this study has demonstrated that the addition of a fermentable carbohydrate to the diet of sheep significantly increases the permeability of the rumen wall to urea, the mechanism by which this response occurs is still unknown.

The authors would like to thank Mr G. F. Brown, MRCVS, for performing the surgery on the sheep, $\mathrm{Mr} \mathrm{D}$. Smith and Miss L. Hedgecock for their care of the experimental animals and Miss C. Pippard and Mrs M. Atherton for their willing assistance with sample collection and analysis. The constructive criticisms of the manuscript by Drs J. V. Nolan and J. P. Hogan are greatly appreciated.

\section{REFERENCES}

Agricultural Research Council (1980). The Nutrient Requirements of Ruminant Livestock. Slough: Commonwealth Agricultural Bureau.

Armstrong, D. G. (1980). The 2nd Tom Miller Memorial Lecture. The North of Scotland College of Agriculture. Ash, R. W. \& Dobson, A. (1963). J. Physiol., Lond. 169. 39.

Chamberlain, D. G., Thomas, P. C. \& Anderson, F. J. (1980). Proc. Nutr. Soc. 39, 29A.

Clarke, R. T. J. \& Reid, C. S. W. (1974). J. Dairy Sci. 57, 753.

Cocimano, M. R. \& Leng, R. A. (1967). Br. J. Nutr. 21, 353.

Coelho da Silva, J. F. (1971). The digestion of nitrogenous constituents in forage and forage-cereal diets by adult sheep, PhD Thesis, University of Newcastle upon Tyne.

Cottyn, B. G. \& Boucque, C. V. (1968). J. Ag. Fd Chem 16, 105.

Engelhardt, W. V., Hinderer, S. \& Wipper, E. (1978). In Ruminant Digestion and Feed Evaluation [D. E. Osbourn, D. E. Beever and D. J. Thomson, editors]. London: Agricultural Research Council.

Hemsley, J. A., Hogan, J. P. \& Weston, R. H. (1975). Aust. J. agric. Res. 26, 715.

Henry, R. J., Cannon, D. C. \& Winkelman, J. W. (1974). Clinical Chemistry - Principles and Techniques. New York: Harper and Row. 
Hinderer, S. \& Engelhardt, W. V. (1975). Comp. Biochem. Physiol. 52A, 619.

Hinks, N. T., Mills, S. C. \& Setchell, B. P. (1966). Analyt. Biochem. 17, 551.

Hogan, J. P. (1961). Aust. J. Biol. Sci. 14, 448.

Houpt, T. R. (1957). Physiologist, Wash. 1, 43.

Houpt, T. R. (1970). In Physiology of Digestion and Metabolism in the Ruminant [A. T. Phillipson, editor]. Newcastle upon Tyne: Oriel Press.

Ishaque, M., Thomas, P. C. \& Rook, J. A. F. (1971). Proc. Nutr. Soc. 30, 1 A.

Kay, R. N. B. (1960). J. Physiol. 150, 515.

Kay, R. N. B. (1966). Wld Rev. Nutr. Dietet. 6, 292.

Kennedy, P. M. (1980). Br. J. Nutr. 43, 125.

Kennedy, P. M. \& Milligan, L. P. (1978) Br. J. Nutr. 39, 105.

Kennedy, P. M. \& Milligan, L. P. (1980) Can. J. Anim. Sci. 60, 205.

Leng, R. A. (1973). In Chemistry and Biochemistry and Herhage, vol. 3, p. 107 [R. W. Bailey and G. W. Butler, editors]. New York: Academic Press.

McMeniman, N. P., Ben Ghedalia, D. \& Armstrong, D. G. (1976). In Protein Metabolism and Nutrition, p. 217 [D. J. A. Cole, editor], London: Butterworths.

MacRae, J. C., Milne, J. A., Wilson, S. \& Spence, A. M. (1979). Br. J. Nutr. 42, 525.

MacRae, J. C., Wilson, S., Milne, J. A. \& Spence, M. (1977). Proc. Nutr. Soc. 37. 16A.

Masson, M. J. \& Phillipson, A. T. (1951). J. Physiol., Lond. 113, 189.

Meggison, P. A., McMeniman, N. P. \& Armstrong, D. G. (1979). Proc. Nutr. Soc. 38, 146A.

Nolan, J. V. \& Leng, R. A. (1972). Br. J. Nutr. 27, 177.

Nolan, J. V., Norton, B. W. \& Leng, R. A. (1976). Br. J. Nutr. 35, 127.

Nolan, J. V. \& Stachiw (1979). Br. J. Nutr. 42, 63.

Norton, B. W., Janes, A. N. \& Armstrong, D. G. (1982). Br. J. Nutr. 48, 265.

Norton, B. W., Murray, R. M., Entwistle, K. W., Nolan, J. V., Ball, F. M. \& Leng, R. A. (1978). Aust. J. agric. Res. 29, 595.

Oldham, J. D., Swan, H. \& Lewis, D. (1973). Proc. Nutr. Soc. 32, 89A.

Orskov, E. R. \& Fraser, C. (1975). Br. J. Nutr. 34, 493.

Potthast, V., Prigge, H. \& Pfeffer, H. (1977). Z. Tierphysiol. Tierenähr Futtermittelk. 38, 338.

Rowe, J. B., Nolan, J. V. \& Leng, R. A. (1978). Proc. Aust. Soc. Anim. Prod. 12, 136.

Simonnet, H., Le Bars, H. \& Molle, J. (1957). C.r. hebd. Séanc. Acad. Sci., Paris 224, 943.

Somers, M. (1961 a). Aust. J. exp. Biol. 39, 111.

Somers, M. (1961 b). Aust. J. exp. Biol. 39, 123.

Stevens, C. E. (1970). In Physiology of Digestion and Metabolism in the Ruminant [A. T. Phillipson, editor]. Newcastle upon Tyne: Oriel Press.

Sutton, J. D. (1979). In Digestive Physiology and Metabolism in Ruminants [Y. Ruckebusch and P. Thivend editors]. Lancaster: MTP Press.

Thorlacius, S. O., Dobson, A. J. \& Sellars, A. F. (1971). Am. J. Physiol. 220, 162.

Thornton, R. F. (1970). Aust. J. agric. Res. 21, 323.

Tribe, D. E. \& Peel, L. J. (1963). Aust. J. agric. Res. 14, 330.

Van Dyne, G. M. \& Torell, D. T. (1964). J. Range Mgmt. 17, 7.

Varady, J., Boda, K. Havassy, I., Bajo, M. \& Tomas, J. (1967). Physiol. Bohemoslov. $16,571$.

Wallace, R. J., Cheng, K. J., Dinsdale, D. \& Ørskov, E. R. (1979). Nature, Lond. $279,424$.

White, R. G., Steel, J. W., Leng, R. A. \& Luick, J. R. (1969). Biochem. J. 114, 203. 